\title{
Astressin Analogues (Corticotropin-Releasing Factor Antagonists) with Extended Duration of Action in the Rat"
}

\author{
J ean Rivier, ${ }^{, \dagger}{ }^{\dagger}$ J ozsef Gulyas, ${ }^{\dagger}$ Anne Corrigan, ${ }^{\dagger}$ Vicente Martinez, ${ }^{\ddagger} \S$ A. Grey Craig, ${ }^{\dagger}$ Yvette Taché, ${ }^{\ddagger}$ \\ Wylie Vale, ${ }^{\dagger}$ and Catherine Rivier ${ }^{\dagger}$
}

The Clayton Foundation Laboratories for Peptide Biology, The Salk Institute for Biological Studies, 10010 North Torrey Pines Road, La J olla, California 92037, CURE/ Digestive Diseases Research Center, West Los Angeles VA Medical Center, 11301 Wilshire Boulevard, Building 115, Room 117, Los Angeles, California 90073, and Department of Physiology, Veterinary School, CEU San Pablo, 46113 Moncada, Valencia, Spain

Received J uly 23, 1998

In earlier reports we identified specific point substitutions (DPhe $\left.{ }^{12}, \mathrm{Nl}^{21,38}\right)$, cyclization strategies [in particular, introduction of lactam rings such as that of cyclo( $\left.\mathrm{Glu}^{30}, \mathrm{Lys}^{33}\right)$ ], and deletions (residues 1-7) in the CRF molecule that led to agonists. We also noted that further deletions (residues 8-14) produced antagonists such as astressin $\left\{\mathrm{cyclo}(30-33)\left[\mathrm{DPhe} \mathrm{P}^{12}, \mathrm{Nle}^{21,38}, \mathrm{Glu}^{30}\right.\right.$, Lys $\left.^{33}\right]$ hCRF $\left.{ }_{(12-41)}\right\}$ (1). We hypothesized that the lactam ring promoted conformational stability to yield analogues with increased potency both in vitro and in vivo as compared to that of their linear counterparts. Additionally, we reported that $\mathrm{cyclo}(30-33)\left[\mathrm{DPhe} \mathrm{e}^{12}, \mathrm{Nle}^{21,38}\right.$, $\left.\mathrm{Glu}^{30}{ }^{\mathrm{DHHis}} \mathrm{DH}^{32}, \mathrm{Lys}^{33}\right] \mathrm{hCRF}_{(12-41)}$ (3) and dicyclo(26-36,30-33)[Ac-Asp ${ }^{9}, \mathrm{DPhe}^{12}, \mathrm{Nle}^{21,38}, \mathrm{Cys}^{26}$, $\mathrm{Glu}^{30}, \mathrm{Lys}^{33}, \mathrm{Cys}^{36}{ }^{36} \mathrm{hCRF}_{(9-41)}$ were ca. twice and 1/100 as potent as astressin, respectively, suggesting a putative turn that encompasses residues 30-33 (previous paper: Koerber et al. $\mathrm{J}$. Med. Chem. 1998, 41). To increase the potency of $\mathbf{1}$ and/or 3 in vivo, we extended their chain length by one $(\mathbf{5}-\mathbf{8})$, two $(\mathbf{9}, \mathbf{1 0})$, and three $(\mathbf{1 1}, \mathbf{1 2})$ residues at the $\mathrm{N}$-terminus and acetylated $(\mathbf{6}, \mathbf{8}, \mathbf{1 0}, \mathbf{1 2})$. Of the compounds tested for duration of action $(\mathbf{1}, \mathbf{3}-\mathbf{6}, \mathbf{8})$, we found $\mathbf{6}$ and $\mathbf{8}$ to be slightly longer-acting than astressin or [DHis ${ }^{32}$ ]astressin, while their potencies in vitro were not significantly different from that of $\mathbf{3}$. Additionally, we introduced $\mathrm{C} \alpha \mathrm{Me}$ leucine residues in lieu of leucine at positions 14, 15, 19, 27, and $37 \mathrm{in}$ [DHis ${ }^{32}$ ]astressin. The analogue $\left[\mathrm{C} \alpha \mathrm{Me}-\mathrm{Leu}^{27}, \mathrm{DH}^{3}{ }^{32}\right]$ astressin (16) was more potent (although not statistically in all cases) than the other four analogues in vitro. While acetylation of the N-terminus of $\mathbf{1 6}$ (i.e., 18) or of $\left[\mathrm{C} \alpha \mathrm{Me}-\mathrm{Leu}^{27}\right]$ astressin (i.e., 19) did not have a significant effect on in vitro potency, elongation of the $\mathrm{N}$-terminus by one or three residues in addition to acetylation resulted in cyclo(30-33) [DPhe $\left.{ }^{12}, \mathrm{Nle}^{21}, \mathrm{C} \alpha \mathrm{Me}-\mathrm{Leu}^{27}, \mathrm{Glu}^{30}, \mathrm{DH}^{3 s^{32}}, \mathrm{Lys}^{33}, \mathrm{Nle}^{38}\right] \mathrm{Ac}-\mathrm{hCRF}(11-41)$ (21), cyclo(3033) $\left[\mathrm{DPhe}{ }^{12}, \mathrm{Nle}^{21}, \mathrm{C} \alpha \mathrm{Me}-\mathrm{Leu}^{27}, \mathrm{Glu}^{30}, \mathrm{Lys}^{33}, \mathrm{Nle}^{38}\right] \mathrm{Ac}^{2} \mathrm{hCRF}_{(9-41)}$ (22), and cyclo(30-33)[DPhe ${ }^{12}$,

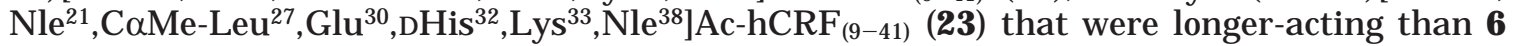
and 8 (ca. $2 \mathrm{~h}$ inhibition of ACTH secretion at $25 \mu \mathrm{g} /$ adrenalectomized rat). Analogues 22 and 23 were also more potent than astressin at reversing intracisternal CRF- and abdominal surgery-induced delay of gastric emptying in conscious rats.

\section{Introduction}

The existence of corticotropin-releasing factor (CRF) was first proposed in 1955 by Guillemin and Rosenberg²

\footnotetext{
"Abbreviations: IUPAC rules are used for nomenclature of peptides including one-letter codes for amino acids. Also: Ac, acetyl; ACTH, adrenocorticotropin hormone; adx, adrenalectomized; astressin, cyclo(30-33)[DPhe $\left.{ }^{12}, \mathrm{Nl}^{21,38}, \mathrm{Glu}^{30}, \mathrm{Lys}^{33}\right]_{\mathrm{hCRF}}(12-41) ; \mathrm{Boc}$, tert-butyloxycarbonyl; BOP, benzotriazolyloxy-tris(dimethylamino)phosphonium hexafluorophosphate; BSA, bovine serum al bumin; CD, circular dichroism CRF, corticotropin-releasing factor (o, ovine; $h$, human); CSF, cerebrospinal fluid; CZE, capillary zone electrophoresis; DCM, dichloromethane; DIC, diisopropylcarbodiimide; DMF, dimethylformamide; FBS, fetal bovine serum; F moc, 9-fluorenylmethoxycarbonyl; HBTU $\mathrm{O}$-(benzotriazol-1-yl)- $\mathrm{N}, \mathrm{N}, \mathrm{N}^{\prime}, \mathrm{N}^{\prime}$-tetramethyluronium hexafluorophosphate; HF, hydrogen fluoride; HOBt, 1-hydroxybenzotriazole; IA, intrinsic activity; ic, intracisternal; LSIMS, liquid secondary ion mass spectrometry; MBHA, 4-methyl benzhydrylamine; NMP, N-methyl pyrrolidinone; NMR, nuclear magnetic resonance; OFm, O-fluorenylmethyl; SAR, structure-activity relationships; TBTU, O-(benzotriazol1-yl)- $\mathrm{N}, \mathrm{N}, \mathrm{N}^{\prime}, \mathrm{N}^{\prime}$-tetramethyluronium tetrafluoroborate; TEAP 2.25, 4.5, and 6.5, triethylammonium phosphate, $\mathrm{pH} 2.25,4.5$, and 6.5; TFA, trifluoroacetic acid; TFE, trifluoroethanol.

* Author for correspondence.

† The Salk Institute for Biological Studies.

₹ West Los Angeles VA Medical Center.

$\S$ CEU San Pablo.
}

and by Saffran and Schally. ${ }^{3}$ I nitially isolated from ovine hypothalamus and shown to be a 41-amino acid peptide in $1981,{ }^{4}$ CRF was subsequently also characterized from rat hypothalami, ${ }^{5}$ and the identical structure was deduced for human CRF on the basis of the CDNA sequence of the human CRF precursor gene. ${ }^{6}$ Presently, more than a dozen members of the CRF family (including sauvagine, urotensins, and urocortins) are known. From the point of view of structure-activity relationships (SAR), those native sequences can have less than $50 \%$ homology and yet exert similar activities (for example, ACTH release, lowering of blood pressure, and inhibition of gastric emptying) and high potencies, with distinct affinities for the different receptor classes and subtypes. ${ }^{7-10}$

Our interest in understanding the SAR of CRF stems from the hypothesis that conditions characterized by an imbalance of CRF might be alleviated by the administration of CRF/CRF agonists or antagonists (see Chrousos and Gold and references therei $\left.n^{11}\right)$. While oCRF and hCRF have been used in the clinic, CRF antagonists 
have not been administered to humans, except for one study with $\alpha$-helical-CRF $(9-41)^{12}$ which suggested the need for anal ogues with increased potency and duration of action. Several observations were made that were critical to the discovery of CRF antagonists with increased potencies. Structural homology ( $\alpha$-helicity) of CRF , sauvagine, and urotensin was predicted by ChouFassman analysis ${ }^{13}$ and documented by circular dichroism (CD) spectrophotometry. ${ }^{14}$ Nuclear magnetic resonance (NMR) spectroscopy confirmed that CRF assumed significant helicity in a mixed organic/aqueous milieu (TFE/water). ${ }^{15,16}$ Earlier, we hypothesized that $\alpha$-helicity might be essential to receptor binding, and we synthesized $\alpha$-helical-CRF that contained, at most positions, the amino acids with the highest $\mathrm{P}_{\alpha}{ }^{13}$ values, found in the then known members of the CRF family. Because $\alpha$-helical-CRF was found to be 3 times as potent as CRF , ${ }^{17}$ we concluded that the bioactive conformation of CRF must be at least in part helical. Systematic deletion of residues at the $\mathrm{N}$-terminus led to the identification of the first CRF antagonist, $\alpha$-helical$\mathrm{CRF}_{(9-41) .}{ }^{17}$ In a systematic scan of the oCRF sequence it was discovered that the [DPhe ${ }^{12}$ ] substitution resulted in a 2-fold increase in potency over that of oCRF.18 Introduction of DPhe at position 12 in [NI $\left.\mathrm{e}^{21,38}\right] \mathrm{rCRF}_{(12-41)}$ yiel ded our most potent antagonist, which has been used as standard in our assays for several years [12 times as potent as $\alpha$-helical-CRF $\left.{ }_{(9-41)}\right]{ }^{18}$ Although $\mathrm{C} \alpha$-methylation of selected leucine and alanine residues resulted in analogues that were somewhat more potent and marginally longer-acting than [DPhe $\left.{ }^{12}, \mathrm{Nle}^{21,38}\right]$ $\operatorname{rCRF}_{(12-41)}, 19$ it was only with the discovery of cyclo(30-33)[DPhe ${ }^{12}, \mathrm{Nle}^{21,38}, \mathrm{Glu}^{30}$, Lys $\left.^{33}\right]$ hCRF (astressin, 1), a compound that is 32 times more potent than [DPhe ${ }^{12}$, $\left.\mathrm{Nle}^{21,38}\right] \mathrm{rCRF}_{(12-41)}, 7,8,20$ that two important structural issues could be addressed: i.e., is the cycl o(30-33) cycle promoting $\alpha$-helicity or is it stabilizing a turn around residues $30-33$ suggested by computer analysis? ${ }^{14} \mathrm{We}$ know that inversion of chirality of certain residues within turns is often well-tolerated, whereas it may destabilize helices. ${ }^{1}$ Because [DHis ${ }^{32}$ ]astressin is ca. twice as potent as astressin (although not statistically different), and because the weakly potent dicyclo(2636,30-33)[Ac-Asp ${ }^{9}$, DP he $^{12}$, Nle ${ }^{21,38}, \mathrm{Cys}^{26}, \mathrm{Glu}^{30}, \mathrm{Lys}^{33}$,Cys $^{36}{ }^{3} \mathrm{hCRF}_{(9-41)}$ is, according to CD data, also highly helical, ${ }^{1}$ we concluded that a turn around residues 3033 could not be excluded and that only NMR data of a highly potent dicyclic anal ogue could resolve that issue (work in progress). In this paper, we reexamine the effect on potency and duration of action of $\mathrm{N}$-terminal lengthening and acetylation and of $\mathrm{C} \alpha$-methylation of the endogenous leucine residues in astressin analogues. End points were $\mathrm{ACTH}$ release [measured in dispersed rat pituitary cells or the adrenalectomized (adx) rat] or gastric emptying (measured in the intact rat). Potency was assessed in the isolated cells, while duration of action was assessed in the adx rat.

\section{Results and Discussion}

All analogues shown in Table 1 were synthesized manually or automatically on a methylbenzhydrylamine (MBHA) resin using the Boc strategy with orthogonal protection of the side chains of the lysine ( $\mathrm{F} \mathrm{moc}$ ) and glutamic acid (OF $\mathrm{m}$ ) resi dues to be cyclized. $8,20-22$ Mainchain assembly was mediated in most cases by diiso- propylcarbodiimide (DIC). The solid-phase assembly of the C $\alpha$-substituted CRF analogues presented some difficulties that were remedied using a 1:1 mixture of benzotriazolyloxy-tris(dimethylamino)phosphonium hexafluorophosphate (BOP)/1-hydroxybenzotriazole (HOBt) $[\mathrm{pH}$ 9-10, $2 \mathrm{~h}$ and the usual excess (3.5-fold) of BocC $\alpha$-methylamino]. ${ }^{19,23}$ In case of incomplete couplings monitored by Kaiser's ninhydrin test, ${ }^{24}$ couplings were repeated followed by acetylation. Cleavage of the F moc and OF $m$ protecting groups was achieved using piperidine after complete assembly of the peptide resin; lactam formation was mediated by TBTU or BOP. ${ }^{20}$ The peptide resins were treated with HF to liberate the fully deblocked crude peptides which were purified using reverse-phase HPLC and three different buffer systems in the foll owing order: TEAP 2.25, TEAP 4.5, or TEAP 6.5 and $0.1 \%$ TFA. ${ }^{20,22,25,26}$ The critical step in obtaining CRF analogues of high purity was that in which we used a TEAP buffer at a pH higher than 4.5 as described earlier. ${ }^{1}$ The highly purified final products were isol ated as the trifluoroacetate salts and characterized using HPLC, CZE, and liquid secondary ionization mass spectrometry (LSI MS) (Table 1). The measured masses obtained using LSIMS were in agreement with those calculated for the protonated molecule ions. The compounds were tested for their ability to antagonize CRF induced release of ACTH by rat pituitary cells in culture. 4,17,27 Duration of action and relative in vivo potency were assessed in the rat in three models: the adx rat for inhibition of ACTH release and the conscious rat to reverse the ic CRF - and abdominal surgeryinduced delay of gastric emptying according to published protocols (Table 2). ${ }^{10}$ We used the rat pituitary cell assay and the adx rat model for the screening of our analogues. With analogues 1-12 we identified the optimum peptide length for maximal potency in vitro; in analogues 13-24 we introduced one C $\alpha M$-leucine as a means to increase structural and biostability.

Structural elements that define members of the astressin family include a D-phenylalanine substitution at position 12 and an optimized 30-33 cycle with an Lor D-residue at position 32 of CRF (12-41). This scaffold, discussed in detail in an earlier paper, ${ }^{1}$ was used as a template for further improvements in potency. Before the discovery of astressin, it was accepted that antagonists which varied in length from $\mathrm{CRF}_{(9-41)}$ to $\mathrm{CRF}_{(12-41)}$ were essentially equipotent. Structural considerations led us to question whether this trend would remain with the introduction of the 30-33 cycle. ${ }^{7}$ More precisely, we had postulated that the structural function of the 3033 cycle was to stabilize (in the antagonist series) an $\alpha$-helical conformation that would otherwise be fulfilled (in the agonist series) by the addition of several residues at the $\mathrm{N}$-terminus. We ther efore sought to optimize the length of the sequence that would also bind to the nonactivated form of the receptor(s). ${ }^{9}$ Additionally, we surmised that acetylation of the $\mathrm{N}$-terminus would be beneficial as a means of helix stabilization and to block aminopeptidase activity. ${ }^{28}$ We next incrementally increased the size of astressin by the addition of one, two, and three residues with $(\mathbf{6}, \mathbf{1 0}, \mathbf{1 2})$ and without $(\mathbf{5}, \mathbf{9}$, 11) acetylation, having shown earlier that the addition of four residues resulted in agonists with essentially full intrinsic activity. ${ }^{1}$ In the same series, two pairs of 
Table 1. Characterization of CRF Antagonists by MS, HPLC, CZE, and in Vitro Relative Potency

$\begin{array}{llllllll}5 & 10 & 15 & 20 & 25 & 30 & 35 & 40\end{array}$

Human/Rat CRF S E E P P I S L D L T F H L L R E V L E M A R A E Q L A Q Q A H S N R K L M I I NH2

\begin{tabular}{|c|c|c|c|c|c|c|c|c|c|}
\hline \multirow[b]{2}{*}{ no. } & \multirow[b]{2}{*}{ CRF antagonists } & \multirow[b]{2}{*}{ HPLCa } & \multirow[b]{2}{*}{ CZE ${ }^{b}$} & \multicolumn{2}{|c|}{ MS (mono) ${ }^{c}$} & \multirow{2}{*}{$\begin{array}{l}\text { relative potencies } \\
\text { in vitro }^{d}\end{array}$} & \multirow[b]{2}{*}{$\mathrm{IA}^{\mathrm{e}}$} & \multirow{2}{*}{$\begin{array}{l}\text { duration } \\
\text { of action }\end{array}$} & \multirow[b]{2}{*}{ ref } \\
\hline & & & & calcd & $\overline{\text { found }}$ & & & & \\
\hline 1 & $\begin{array}{c}\text { cyclo(30-33)[DPhe }{ }^{12}, \mathrm{Nle}^{21}, \mathrm{Glu}^{30}, \mathrm{Lys}^{33}, \\
\mathrm{Nle}^{38} \mathrm{hCRF}_{(12-41} \text { (astressin) }\end{array}$ & 95 & 97 & 3562.13 & 3562.2 & $32^{\ddagger}$ & $0-5$ & SA & 7 \\
\hline 2 & $\begin{array}{l}\text { cyclo(30-33)[DPhe }{ }^{12}, \mathrm{Nle}^{21}, \mathrm{Glu}^{30}, \mathrm{Lys}^{33} \\
\left.\mathrm{Nle}^{38}\right]_{\mathrm{Ac}}\end{array}$ & 95 & 96 & 3604.06 & 3604.1 & $37(19-67)^{\ddagger}$ & 3 & & 1 \\
\hline 3 & $\begin{array}{l}\text { Cyclo(30-33)[DPhe } \mathrm{DP}^{12}, \mathrm{Nle}^{21}, \mathrm{Glu}^{30}, \mathrm{DHis}^{32} \\
\left.\text { Lys }^{33}, \mathrm{Nle}^{38}\right]_{\text {hCRF }}(12-41)\end{array}$ & 97 & $>97$ & 3562.05 & 3562.4 & $\begin{array}{l}56^{\ddagger} \\
1.00^{\ddagger \ddagger}\end{array}$ & $\begin{array}{r}30 \\
1 \\
25\end{array}$ & SA & 1 \\
\hline 4 & 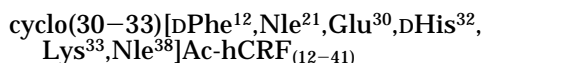 & 94 & 90 & 3604.06 & 3604.1 & $1.2(0.41-3.3)^{\ddagger \neq}$ & 10 & SA & 1 \\
\hline 5 & $\begin{array}{l}\text { cyclo(30-33)[DPhe }{ }^{12}, \mathrm{Nle}^{21}, \mathrm{Glu}^{30}, \mathrm{Lys}^{33} \\
\left.\mathrm{Nle}^{38}\right]_{\mathrm{hCRF}} \\
(11-41)\end{array}$ & 95 & 97 & 3663.10 & 3663.2 & $40(28-72)^{\ddagger}$ & 18 & SA & \\
\hline 6 & $\begin{array}{l}\text { cyclo(30-33)[DPhe }{ }^{12}, \mathrm{Nle}^{21}, \mathrm{Glu}^{30}, \mathrm{Lys}^{33} \\
\left.\mathrm{Nle}^{38}\right] \mathrm{Ac}-\mathrm{hCRF}_{(11-41)}\end{array}$ & $>97$ & $>97$ & 3705.11 & 3705.1 & $\begin{array}{l}64(33-129)^{\ddagger} \\
4.4(2.7-7.1)^{\ddagger \ddagger} \\
2.0(0.87-4.7)^{\ddagger \ddagger}\end{array}$ & $\begin{array}{r}6 \\
17 \\
14\end{array}$ & $\mathrm{SA}+$ & \\
\hline 7 & 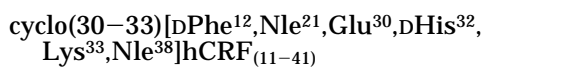 & 95 & 80 & 3663.10 & 3663.2 & $0.78(0.41-1.5)^{\ddagger \ddagger}$ & 12 & & \\
\hline 8 & $\begin{array}{l}\text { Cyclo(30-33)[DPhe }{ }^{12}, \mathrm{Nle}^{21}, \mathrm{Glu}^{30}, \mathrm{DHis}^{32} \\
\left.\text { Lys }^{33}, \mathrm{Nle}^{38}\right]_{\mathrm{Ac}} \mathrm{hCRF}_{(11-41)}\end{array}$ & 95 & 90 & 3705.11 & 3705.2 & $\begin{array}{l}3.1(1.1-7.8)^{\ddagger \ddagger} \\
1.7(0.88-3.4)^{\ddagger \ddagger}\end{array}$ & $\begin{array}{r}11 \\
7\end{array}$ & $\mathrm{SA}+$ & \\
\hline 9 & $\begin{array}{l}\text { cyclo(30-33)[DPhe }{ }^{12}, \mathrm{Nle}^{21}, \mathrm{Glu}^{30}, \mathrm{Lys}^{33} \\
\left.\mathrm{Nle}^{38}\right]_{\mathrm{hCRF}}(10-41)\end{array}$ & $>97$ & $>97$ & 3776.18 & 3776.1 & $\begin{array}{l}17(9.1-31.3)^{\ddagger} \\
\quad 32(14-65)^{\ddagger}\end{array}$ & $\begin{array}{l}18 \\
27\end{array}$ & & \\
\hline 10 & $\begin{array}{l}\text { cyclo(30-33)[DPhe }{ }^{12}, \mathrm{Nle}^{21}, \mathrm{Glu}^{30}, \mathrm{Lys}^{33} \\
\left.\text { Nle }^{38}\right]_{\text {Ac-hCRF }}{ }_{(10-41)}\end{array}$ & 96 & $>97$ & 3818.19 & 3818.1 & $\begin{array}{l}32(16-69)^{\ddagger} \\
2.5(1.5-4.0)^{\ddagger \ddagger}\end{array}$ & $\begin{array}{l}22 \\
17\end{array}$ & & \\
\hline 11 & $\begin{array}{l}\text { cyclo(30-33)[DPhe }{ }^{12}, \mathrm{Nle}^{21}, \mathrm{Glu}^{30}, \mathrm{Lys}^{33} \\
\left.\mathrm{Nle}^{38}\right] \mathrm{hCRF}(9-41)\end{array}$ & 97 & $>97$ & 3891.21 & 3891.7 & $0.27(0.13-0.53)^{\ddagger \neq}$ & 28 & & \\
\hline 12 & $\begin{array}{l}\text { cyclo(30-33)[DPhe }{ }^{12}, \mathrm{Nle}^{21}, \mathrm{Glu}^{30}, \mathrm{Lys}^{33}, \\
\left.\mathrm{Nle}^{38}\right] \mathrm{Ac}-\mathrm{hCRF}(9-41)\end{array}$ & $>97$ & $>97$ & 3933.22 & 3933.0 & $\begin{array}{l}172(68-522)^{\ddagger} \\
0.77(0.40-1.5)^{\ddagger \ddagger} \\
2.0(1.1-3.7)^{\ddagger \ddagger}\end{array}$ & $\begin{array}{r}21 \\
0 \\
24 \\
18\end{array}$ & & \\
\hline 13 & 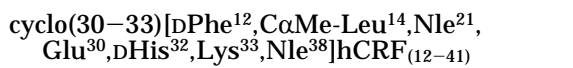 & 93 & 92 & 3576.07 & 3576.1 & $15(7.5-29)^{\ddagger}$ & 12 & & \\
\hline 14 & $\begin{array}{l}\text { cyclo(30-33)[DPhe }{ }^{12}, \mathrm{C} \alpha M \mathrm{MeLeu} \mathrm{Lu}^{15}, \mathrm{Nle}^{21} \\
\left.\mathrm{Glu}^{30}, \mathrm{DHis}^{32}, \mathrm{Lys}^{33}, \mathrm{Nle}^{38}\right] \mathrm{hCRF}_{(12-41)}\end{array}$ & 93 & 99 & 3576.07 & 3576.1 & $20(12-37)^{\ddagger}$ & 11 & & \\
\hline 15 & $\begin{array}{l}\text { cyclo(30-33)[DPhe }{ }^{12}, \mathrm{C} \alpha M \mathrm{Me} \mathrm{Leu}^{19}, \mathrm{Nle}^{21} \\
\left.\mathrm{Glu}^{30}, \mathrm{DHis}^{32}, \mathrm{Lys}^{33}, \mathrm{Nle}^{38}\right] \mathrm{hCRF}_{(12-41)}\end{array}$ & 100 & 98 & 3576.07 & 3576.0 & $4.5(1.9-9.7)^{\ddagger}$ & 4.7 & & \\
\hline 16 & $\begin{array}{l}\text { cyclo(30-33)[DPhe }{ }^{12}, \mathrm{Nle}^{21}, \mathrm{C} \alpha M e-L e u^{27} \\
\text { Glu }^{30}, \mathrm{DHis}^{32}, \mathrm{Lys}^{33}, \mathrm{Nle}^{38} \mathrm{hCRF}_{(12-41)}\end{array}$ & 96 & 98 & 3576.07 & 3576.1 & $\begin{array}{l}54(26-112)^{\ddagger} \\
0.89(0.42-1.8)^{\ddagger}\end{array}$ & $\begin{array}{l}7.4 \\
0\end{array}$ & SA & \\
\hline 17 & 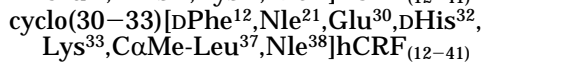 & 88 & 84 & 3576.07 & 3570.0 & $16(9.3-26)^{\ddagger}$ & 17 & & \\
\hline 18 & 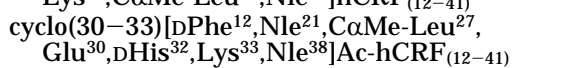 & 99 & 99 & 3618.08 & 3618.0 & $0.54(0.20-1.2)^{\ddagger \ddagger}$ & 0 & & \\
\hline 19 & $\begin{array}{l}\text { cyclo(30-33)[Nle } \mathrm{N}^{21}, \mathrm{C} \alpha \mathrm{Me}-\mathrm{Leu}^{27}, \mathrm{Glu}^{30} \\
\left.\text { Lys }^{33}, \mathrm{Nle}^{38}\right] \mathrm{Ac}-\mathrm{hCRF}_{(12-41)}\end{array}$ & 90 & 97 & 3618.08 & 3618.0 & $\begin{array}{l}1.7(0.6-4.1)^{\ddagger \ddagger} \\
0.42(0.18-0.92)^{\ddagger \ddagger}\end{array}$ & $\begin{array}{l}0 \\
6\end{array}$ & & \\
\hline 20 & 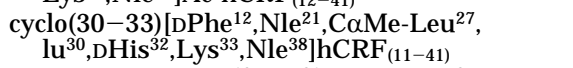 & 95 & 90 & 3677.11 & 3677.2 & $1.3(0.74-2.2)^{\ddagger \ddagger}$ & & SA & \\
\hline 21 & $\begin{array}{l}\text { cyclo(30-33) }\left[\mathrm{DPhe}^{12}, \mathrm{Nle}^{21}, \mathrm{C}^{3} \mathrm{Me}-\mathrm{Leu}^{27}\right. \\
\left.\mathrm{Glu}^{30}, \mathrm{DHis}^{32}, \mathrm{Lys}^{33}, \mathrm{Nle}^{38}\right] \mathrm{Ac}-\mathrm{hCRF}(11-41)\end{array}$ & 98 & $\begin{array}{l}\text { NA } \\
\text { too } \\
\text { phobic }\end{array}$ & $3719-12$ & 3719.2 & $1.4(0.74-2.7)^{\ddagger \neq}$ & 10 & MA & \\
\hline 22 & $\begin{array}{l}\text { cyclo(30-33)[DPhe }{ }^{12}, \mathrm{Nle}^{21}, \mathrm{C} \alpha \mathrm{Me}-\mathrm{Leu}^{27} \\
\text { Glu }^{30}, \mathrm{Lys}^{33}, \mathrm{Nle}^{38} \mathrm{Ac}^{2}-\mathrm{hCRF}_{(9-41)}\end{array}$ & 93 & 92 & 3947.23 & 3947.9 & $\begin{array}{l}1.7(0.6-4.2)^{\ddagger \ddagger} \\
0.67(0.41-1.1)^{\ddagger \ddagger}\end{array}$ & 12 & MA & \\
\hline 23 & $\begin{array}{l}\text { cyclo(30-33)[DPhe }{ }^{12}, \mathrm{Nle}^{21}, \mathrm{C} \alpha M e-L \mathrm{Meu}^{27} \\
\left.\mathrm{Glu}^{30}, \mathrm{DHis},{ }^{32} \mathrm{Lys}^{33}, \mathrm{Nle}^{38}\right] \mathrm{Ac}-\mathrm{hCRF} \\
(9-41)\end{array}$ & 100 & NA & 3947.23 & 3947.2 & $\begin{array}{l}3.9(2.1-7.5)^{\ddagger \ddagger} \\
0.49(0.30-0.79)^{\ddagger \ddagger}\end{array}$ & 23 & MA & \\
\hline 24 & $\begin{array}{l}\mathrm{Cyclo}(30-33)\left[\mathrm{DPhe}^{12}, \mathrm{C} \alpha \mathrm{Me}-\mathrm{Leu}^{15}, \mathrm{Nle}^{21}\right. \\
\left.\left.\text { Glu }^{30}, \mathrm{DH} \text { is(im-Bzl }\right),{ }^{32} \mathrm{Lys}^{33}, \mathrm{Nle}^{38}\right] \mathrm{hCRF}(12-41)\end{array}$ & 96 & 96 & 3666.11 & 3666.2 & $24(14-39)^{\ddagger}$ & 13 & & \\
\hline
\end{tabular}

a Percent purity determined by HPLC using buffer system: $\mathrm{A}=\mathrm{TEAP}(\mathrm{pH} 2.5)$ and $\mathrm{B}=60 \% \mathrm{CH}_{3} \mathrm{CN} / 40 \% \mathrm{~A}$ with a gradient slope of $1 \% \mathrm{~B} / \mathrm{min}$, at a flow rate of $0.2 \mathrm{~mL} / \mathrm{min}$ on a Vydac $\mathrm{C}_{18}$ column $(0.21 \times 15 \mathrm{~cm}, 5-\mu \mathrm{m}$ particle size, $300-\AA$ pore size), detection at $214 \mathrm{~nm}$. ${ }^{b}$ Capillary zone electrophoresis (CZE) was done using a Beckman P/ACE System 2050 controlled by an IBM Personal System/2 model $50 \mathrm{Z}$ and using a Chroml et integrator. Field strength of $15 \mathrm{kV}$ at $30{ }^{\circ} \mathrm{C}$, mobile phase $100 \mathrm{mM}$ sodium phosphate $\left(85: 15 \mathrm{H}_{2} \mathrm{O}-\mathrm{CH}_{3} \mathrm{CN}\right)$, $\mathrm{pH} 2.50$, on a Supel co P175 capillary (363- $\mu \mathrm{m}$ o.d. $\times 75-\mu \mathrm{m} \mathrm{i.d.} \times 50-\mathrm{cm}$ length), detection at $214 \mathrm{~nm}$. ${ }^{\mathrm{C}}$ The observed m/z of the monoisotope compared with the calculated $[\mathrm{M}+\mathrm{H}]^{+}$monoisotopic mass. ${ }^{d}$ Antagonist potencies are relative to that of $\left[\mathrm{DPhe}^{12}, \mathrm{Nle}^{21,38}\right] \mathrm{hCRF}(12-41)^{\ddagger}$ or

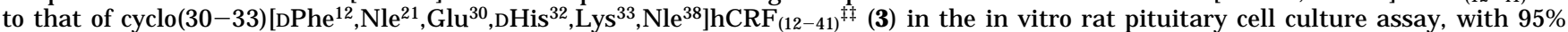
confidence limits in parentheses. Potencies of $\mathbf{1}$ and $\mathbf{3}$ relative to that of [DPhe ${ }^{12}, \mathrm{Nle}^{21,38} \mathrm{hCRF}_{(12-41)^{\ddagger}}$ are average of three assays. ${ }^{\mathrm{e}} \mathrm{The}$ percent intrinsic activity (IA) of each of the antagonists is calculated by determining the level of secretion caused by the highest dose of antagonist (in the absence of oCRF) minus basal secretion, dividing that number by the level of secretion of $1 \mathrm{nM}$ oCRF minus basal secretion, and multiplying the result by 100 . IA values for $\mathbf{1}$ and $\mathbf{3}$ are the average of three assays. ${ }^{\mathrm{f}}$ Definition of duration of action in the adx rat after iv administration of $25 \mu \mathrm{g}$ of peptide/rat (100 $\mu \mathrm{g} / \mathrm{kg})$ : short acting (SA), duration of action less than 90 min; medium acting (MA), shows complete inhibition at $120 \mathrm{~min}$ and no detectable standard error, with partial recovery at $180 \mathrm{~min}$.

analogues with [DHis ${ }^{32}$ ] $\mathbf{3}$ and $\mathbf{7}$ are the nonacetylated homologues of $\mathbf{4}$ and $\mathbf{8}$ ) were also synthesized and tested. It should be noted that the introduction of the [DHis ${ }^{32}$ ] substitution resulted in two cases in doubling in in vitro potency over that of the corresponding analogues without [ $\mathrm{DH} \mathrm{is}^{32}$ ] ( $\mathbf{3}$ and $\mathbf{4}$ are approximately twice as potent as the corresponding antagonists $\mathbf{1}$ and $\mathbf{2}$ although not statistically different) and in two cases resulted in no improvement of potency (the two pairs of analogues $\mathbf{5}$ and $\mathbf{7}$ and $\mathbf{6}$ and $\mathbf{8}$ being equipotent). Elongation of astressin by one residue $(\mathbf{5}, \mathbf{7})$ has no effect on potency, while additional acetylation $(\mathbf{6}, \mathbf{8})$ may 
CRF Antagonists with Extended Duration of Action

Table 2. Comparison of CRF Antagonists' ED50'S To Block Intracisternal CRF- and Abdominal Surgery-I nduced I nhibition of Gastric Emptying in Conscious Rats

\begin{tabular}{lll}
\hline \multicolumn{1}{c}{ CRF antagonist } & \multicolumn{1}{c}{ CRF } & abdominal surgery \\
\hline [DPhe $^{12}, \mathrm{Nle}^{21,38} \mathrm{hCRF}_{12-41}$ & $6.3(4.7-8.5)$ & $5.9(4.0-8.8)$ \\
& 0.994 & 0.994 \\
astressin & $1.5(0.8-2.9)$ & $1.3(0.41-4.4)$ \\
& 0.973 & 0.970 \\
22 & $0.11(0.092-0.14)$ & $0.11(0.075-0.15)$ \\
23 & 0.999 & 0.997 \\
& $0.14(0.12-0.16)$ & $0.17(0.085-0.33)$ \\
\hline
\end{tabular}

a Data represent $\mathrm{ED}_{50}$ values ( $\mu \mathrm{g} / \mathrm{rat}$, ic) with the respective $95 \%$ confidence interval (in parentheses) and the $r^{2}$ according to a nonlinear regression model.

double potency. In comparing the potency of $\mathbf{5}$ to that of $\mathbf{7}$ (each tested against a different standard), we assume that $\mathbf{3}$ is 56 times more potent than [DPhe ${ }^{12}$, $\left.\mathrm{Nle}^{21,38}\right]_{h C R F}(12-41)$ and that the potency of $\mathbf{7}$ against the same standard as the one used for $\mathbf{5}$ would be 0.78 $\times 56=44$. We have found this converting factor to be quite accurate in some cases when the same anal ogues were tested against the two standards (16) and less so in others $(\mathbf{6}, \mathbf{1 0}, \mathbf{1 2})$. It would take several assays of the same compounds against the two standards to reconcile these data. Further elongation without acetylation results in loss of potency $(\mathbf{9}, \mathbf{1 1})$, yet acetylation of these anal ogues may restore potency $(\mathbf{1 0}, \mathbf{1 2})$. These observations suggest that our in vitro assay is remarkably sensitive to minor changes in both primary and secondary structure of the anal ogues. The question, however, can be raised whether those differences in potencies (such as doubling) which are not statistically different (overlapping 95\% confidence limits) can be used for the identification of useful substitutions. Data from our laboratory support that such trends observed in several series are generally indicative of a real effect that confirms intuitive (although statistically not significant) rankings in potency.

In the adx rat, astressin (1) significantly $(P<0.01)$ lowered plasma ACTH levels for at least $60 \mathrm{~min}$ (Figure $1 A, B)$. Compounds 3 and 4 were only effective $(P<0.01)$ for 30 and $60 \mathrm{~min}$, respectively (Figure $1 \mathrm{~A}$ ), while 5, 6, and 8 were effective $(P<0.05-0.01)$ for at least $90 \mathrm{~min}$ (5, Figure 1B) or $120 \mathrm{~min}(\mathbf{6}$ and $\mathbf{8}$, Figure 1B). By our definition, we consider $\mathbf{6}$ and $\mathbf{8}$ to still be short-acting. In summary, while in earlier studies, we had identified the $\mathrm{Glu}^{30}-\mathrm{Lys}^{33}$ cycle and the [DPhe ${ }^{12}$ ] and [DHis ${ }^{32}$ ] substitutions as being favorable, the above data indicated that acetylation of the N-terminus of CRF antagonists may also have favorable effects on potency and duration of action.

At this point we decided to capitalize on the past observation that substitutions by $\mathrm{C} \alpha \mathrm{Me}$-Leu residues had measurable effects on the potency and duration of action of CRF antagonists. ${ }^{19}$ We therefore substituted leucines at positions 14, 15, 19, 27, and 37 of astressin and [DH is ${ }^{32}$ ]astressin with $\mathrm{C} \alpha \mathrm{Me}$-Leu (structures shown in Table 1). We hypothesized that this residue might block the action of endopeptidases in ways that could not be achieved with the introduction of D-residues al one. ${ }^{18}$

In a first step, we substituted leucines at positions $14,15,19,27$, and 37 of $\mathbf{3}$ with C $\alpha$ Me-Leu to yield $\mathbf{1 3}-$ 17 with in vitro potencies of $15,20,4.5,54$, and 16 ,
J ournal of Medicinal Chemistry, 1998, Vol. 41, No. 255015

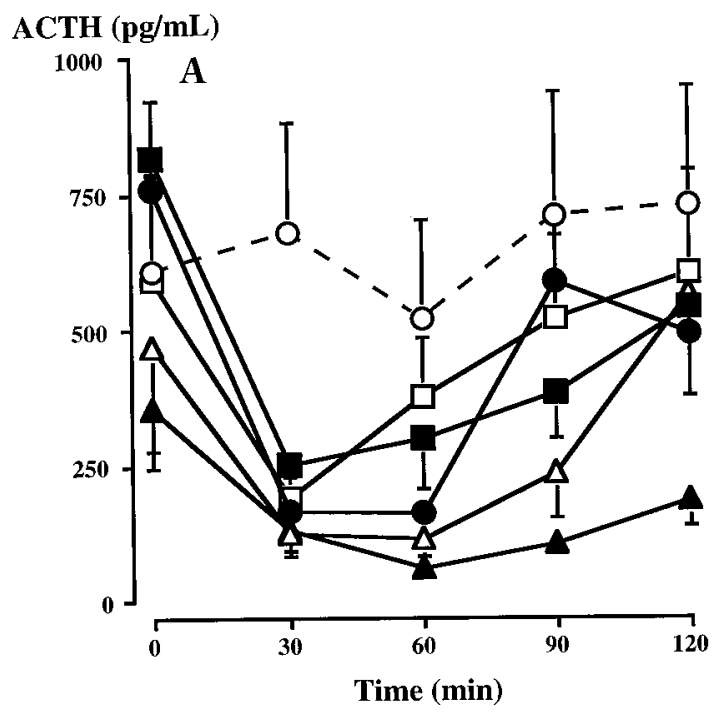

ACTH $(\mathrm{pg} / \mathrm{mL})$
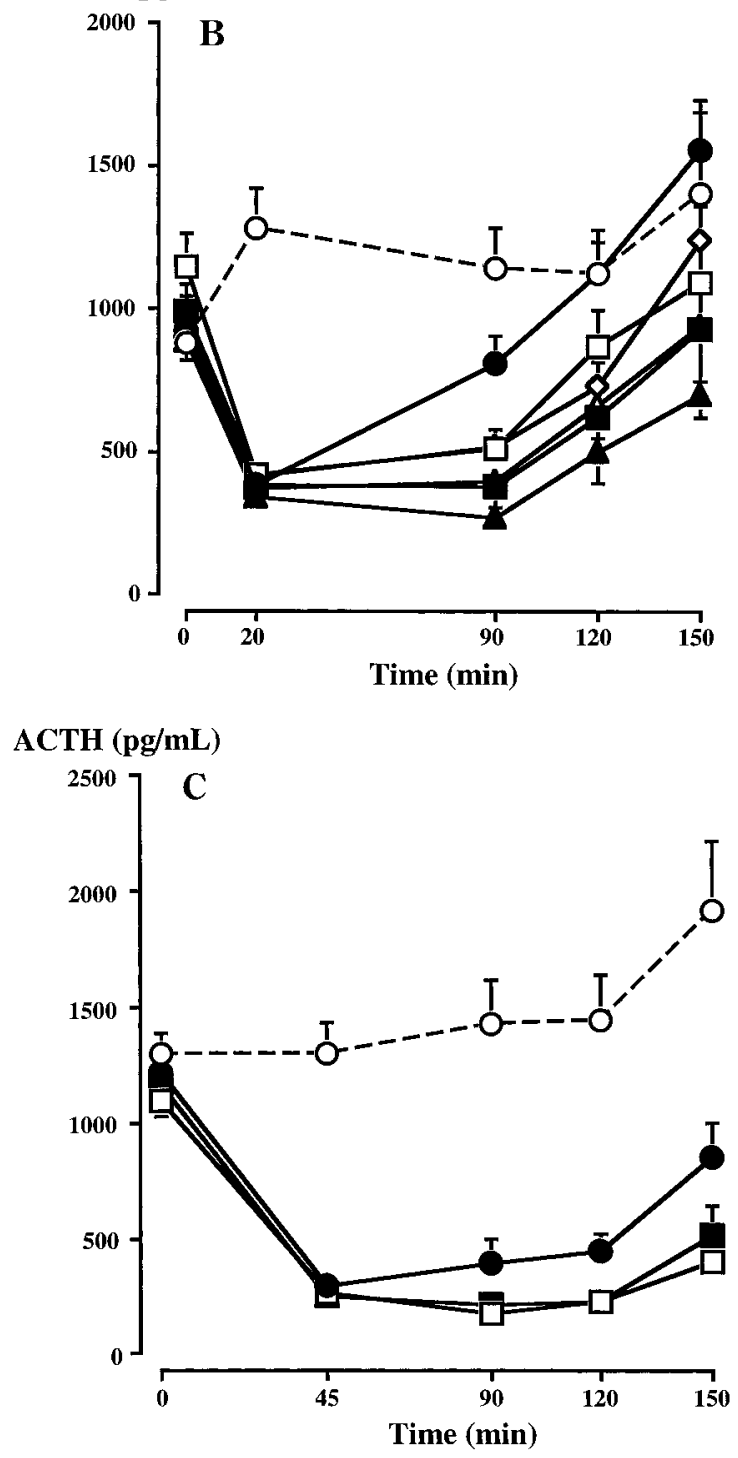

Figure 1. Effect of CRF antagonists ( $25 \mu \mathrm{g} / \mathrm{rat}$ iv) on ACTH secretion in adx rats. Each point represents the mean \pm SEM of 3-7 animals. When not visible, SEM are encompassed within the symbol; control, O. 1A: 1, $\mathbf{0 ;} \mathbf{3}, \square ; \mathbf{4}, \mathbf{\square} ; \mathbf{1 6}, \Delta ; \mathbf{2 1}$, $\triangle$. 1B: $1, \bullet ; 5, \square ; 6, \square ; 8, \triangle ; 21, \triangle ; 20, \diamond .1 C: 21, \bullet ; 22, \square ; \mathbf{2 3}$, 
respectively, that are relative to that of $\left[\mathrm{DPhe}^{12}\right.$, $\left.\mathrm{Nle}^{21,38}\right] \mathrm{hCRF}_{(12-41)}$ (potency $=1$ ). When tested against the parent analogue $\mathbf{3}$, these peptides were approximately $0.25,0.33,0.08,1.0$, and 0.25 as potent as $\mathbf{3}$. These results suggested that $\mathrm{C} \alpha \mathrm{Me}-\mathrm{Leu}^{27}$ at position 27 was well-tolerated and that the other leucines (at positions 14, 15, 19, and 37) were particularly sensitive to modifications as minor as the introduction of a C $\alpha \mathrm{Me}$ group which is predicted to favor helicity. This substitution by itself, however, had a minor beneficial effect on duration of action [16 is longer-acting than $\mathbf{3}$ (Figure $1 \mathrm{~A})$, although both are considered short-acting by our definition]. It is noteworthy that substitutions of leucines at positions 14, 15, 19, 27, and 37 in oCRF by norleucines yielded analogues that, except for $\left[\mathrm{Nle}^{14}\right]$ OCRF (with decreased binding affinity), had similar affinities for the CRF receptor as $\mathrm{CRF}^{29}$ suggesting that the C $\alpha$ Me-Leu substitution may be more discriminating than a norleucine substitution. This may point to the enhanced susceptibility of the receptor for conformational rather than for steric parameters at these positions. Acetylation of the $\mathrm{N}$-terminus of $\mathbf{1 6}$ and retention of the L-configuration of $\mathrm{His}^{32}$ yielded $\mathbf{1 8}$ and $\mathbf{1 9}$ that were essentially equipotent in vitro to their closest homologue 16. Since $\mathbf{6}$ may be longer-acting than $\mathbf{5}$ (Figure 1B), we synthesized $\mathbf{2 0}$ and $\mathbf{2 1}$ which also showed an improvement in duration of action. While in the adx rat, 1 significantly $(P<0.01$ ) lowered plasma ACTH levels for $60-90$ min (Figure $1 A, B$ ), 16, 20, and 21 were effective $(P<0.05-0.01)$ for at least $90 \mathrm{~min}$ (16, Figure 1A), $120 \mathrm{~min}$ (20 Figure 1B), or $150 \mathrm{~min}$ (21, Figure $1 A-C)$, and $\mathbf{2 2}$ and $\mathbf{2 3}$ were effective for $>\mathbf{1 5 0}$ min (Figure 1C). Although being equipotent in vitro, 21 inhibited ACTH secretion in the adx rat for at least 2.5 $\mathrm{h}$ which was almost twice the duration of action of $\mathbf{2 0}$ (Figure 1B) under the same experimental conditions. Although no in vivo data are available for 18 and 19, comparison of the duration of action of $\mathbf{2 0}$ and $\mathbf{2 1}$ may suggest that $\mathbf{1 8}$ would be longer-acting than $\mathbf{1 6}$ (Figure $1 \mathrm{~A})$. When comparing the duration of action of $\mathbf{2 2}$ and 23, it was evident that acetylation of the $\mathrm{N}$-terminus was more important than the presence of either L- (22) or D-histidine (23) at position 32. Addition of CaMe$\mathrm{Leu}^{27}$ and at least one residue (AC-Thr ${ }^{11}$ ) (21) or three residues $\left(\mathrm{Ac}-\mathrm{Asp}^{9}, \mathrm{Leu}^{10}, \mathrm{Thr}^{11}\right)(\mathbf{2 3})$ at the $\mathrm{N}$-terminus of $\mathbf{1}$ had a marked effect on duration of action, extending it by a factor of at least 3 over that of $\mathbf{1}$. It is noteworthy that $\mathbf{1}$ and $\mathbf{2 1}$, tested in two/three consecutive in vivo assays (respectively), consistently gave the same duration of action (Figure $1 \mathrm{~A}-\mathrm{C}$ ) suggesting that the subtle differences in duration of action seen between analogues is likely reflecting a unique property of each analogue. It is on the basis of a number of such observations that we have gained confidence in using what appeared as modifications with marginal effects in the design of ever more potent and longer-acting analogues.

We then sought to confirm the results obtained with the adx rats in two additional bioassays. We had previously shown that, after injection in the cerebrospinal fluid (CSF) at the level of the cisterna magna, CRF antagonists reversed CRF - and stress-induced gastrointestinal (GI) motor alterations. ${ }^{10}$ In Table 2 we compare the $\mathrm{ED}_{50}$ 's of $\mathbf{2 2}$ and $\mathbf{2 3}$ injected into the CSF, to block CRF - and abdominal surgery-induced inhibition of gastric emptying in conscious rats, to that of $\left[\mathrm{DPhe}^{12}, \mathrm{Nle}^{21,38}\right]_{\mathrm{hCRF}}{ }_{(12-41)}$ and astressin. Both antagonists showed similar high potency and long-lasting activity in these assays. Both compounds were, based on their ED 50 's, about 10 times more potent than the related compound astressin and about 40 times more potent than the previously developed CRF antagonist $\left[\mathrm{DPhe}{ }^{12}, \mathrm{Nle}^{21,38}\right] \mathrm{hCRF}_{(12-41)}$ in these systems. These results further strengthen the important role of CRF in stress-related alterations of gastrointestinal motor functions and the potential therapeutic interest of CRF antagonists to prevent postoperative ileus.

One further attempt to increase duration of action stemmed from an earlier observation that histidine containing peptides become significantly less watersoluble at physiological pH as compared to their aqueous solubility at acidic $\mathrm{pH}$. We have shown that this property can be further enhanced by the introduction of a benzyl group on the imi dazole ring. ${ }^{30}$ Since potency can be influenced by steric effects and duration of action can be modulated by hydrophobicity, we introduced $\mathrm{DHis}(\mathrm{im}-\mathrm{Bz})$ at position 32 of $\mathbf{1 4}$. The observation that $\mathbf{2 4}$ is equipotent to $\mathbf{1 4}$ demonstrates that bulky Dresidues can be accommodated at that position, as suggested by model studies in which a turn encompassing residues $30-33$ has been introduced. ${ }^{1}$

In conclusion, extension of astressin's and [ $\left.\mathrm{DH} \mathrm{is}^{32}\right]$ astressin's sequence by one to three residues, acetylation of the $\mathrm{N}$-terminus, and introduction of [C $\left.\alpha \mathrm{Me}-\mathrm{Leu}^{27}\right]$ yielded a family of analogues with increased potency and extended duration of action as compared to that of astressin. It is suspected that Leu ${ }^{27}$ is either sensitive to enzymatic cleavage (which is blocked by the introduction of the CaMe group) or unique in its ability to maintain the overall bioactive conformation of CRF and is ther efore likely to be helical around that residue. We have shown that the adx rat model and the reversal of CRF - or stress-induced delay of gastric emptying are three unusually reliable tools for SAR studies and optimization of pharmacokinetics in the rat. As in general the rat is a good model of human physiology, our data suggest that potent and long-acting CRF antagonists may be obtainable for use in the clinic. Yet, the limited duration of action of even the longest-acting known CRF antagonists (21-23) (as compared to that of other peptides such as GnRH antagonists ${ }^{31}$ or melanotropin derivatives ${ }^{32}$ ) indicates that there may be other (biochemically or structurally) unrecognized sensitive regions in 21-23 that could be optimized to yield extended duration of action. Interestingly, the amino acids of the CRF molecule successfully modified in this report (positions 12, 21, 27, 30, 32, 33, and 38) to yield relatively long-acting CRF antagonists are not those shown to be sensitive to brain enzymes (positions 1, 11, $13,15,23,35$, and 36). ${ }^{33}$ We acknowledge that, although these results suggest that CRF and CRF antagonists may have different sensitivities to central and peripheral enzymatic extracts, further data (including receptor affinity and peptide diffusion/transport) need to be obtained on the effect of substitutions of the sensitive amino acids at positions 1, 11, 13, 15, 23, 35, and 36 by unnatural ones and, possibly most importantly, on the effect of acetylation of the $\mathrm{N}$-terminus. 


\section{Experimental Section}

Synthesis of CRF Analogues. All analogues shown in Table 1 were synthesized either manually or on a Beckman 990 peptide synthesizer using the solid-phase approach, the MBHA resin, ${ }^{20}$ and the Boc strategy with orthogonal protection ( $\mathrm{Fmoc}$ and $\mathrm{OF} \mathrm{m}$ ) of the side chains of residues to be cyclized. ${ }^{21}$ Amino acid derivatives Boc-Ala, Boc-Arg(Tos), Boc-Asn(Xan), Boc-Asp(cHex), Boc-GIn(Xan), Boc-Glu(cHex), Boc-His(Tos), Boc-Ile, Boc-Met, Boc-Leu, Boc-Phe, Boc-Pro, Boc-Ser(Bzl), Boc$\operatorname{Thr}(\mathrm{Bzl}), \mathrm{Boc}-\mathrm{Tyr}(2-\mathrm{Br}-\mathrm{Cbz})$, and Boc-Val were obtained from Bachem I nc. (T orrance, CA), Chem-Impex International (Wood Dale, IL), and Cal biochem (San Diego, CA). Boc-C ${ }^{\alpha M e-L L e u,}{ }^{19}$ Boc-Glu(OFm), and Boc-Lys(F moc) ${ }^{34}$ were synthesized (and resolved where applicable) as described earlier. All solvents were reagent grade or better. TFA, $50-60 \%$ in DCM $(1 \%$ $\mathrm{m}$-cresol), was used to remove the Boc group. Main-chain assembly was mediated by DIC. Three-fold excess protected amino acid was used based on the original substitution of the MBHA resin. When the synthesis was carried out on a synthesizer, coupling time was 90-120 min followed by recoupling after residue 32 (with the exception of glycine and alanine residues which were not recoupled). Automatic acetylation (excess acetic anhydride in DCM for $15 \mathrm{~min}$ ) was carried out after addition of each amino acid. When synthesized manually, recouplings were carried out only when necessary and acetylations only when recoupling could not yield negative ninhydrin tests. ${ }^{24}$ Deprotection of the F moc group was achieved using a fresh solution of $20 \%$ piperidine/DMF or NMP $(2 \times 10$ min) followed by sequential washes with $\mathrm{DMF}, \mathrm{MeOH}, 10 \%$ TEA/DCM, and DCM. Lactam formation was mediated using TBTU or HBTU in DMF or NMP. Best results were obtained when the peptide chain was assembled in its entirety prior to cleavage of the F moc and Ofm protecting groups and cyclization as shown earlier. ${ }^{20}$ The peptides were cleaved and deprotected in HF in the presence of anisole $(5-10 \%, v / v)$ and purified using RP-HPLC and three solvent systems (TEAP at $\mathrm{pH} 2.25$, TEAP at $\mathrm{pH} 4.5-6.5$, and $0.1 \%$ TFA, successively). ${ }^{25,26}$

Characterization of CRF Analogues. Peptides were characterized as shown in Table 1 and below. Most anal ogues were greater than $95 \%$ pure with no impurity greater than $1 \%$ using independent HPLC and CZE criteria and had expected masses.

A. RP-HPLC. In addition to determining the purity of the peptides in an acidic system (see Table 1 legend), most of the analogues were also analyzed using $0.05 \%$ TEAP at pH 6.8 and a Vydac $\mathrm{C}_{8}$ column $(0.21 \times 15 \mathrm{~cm})$ at a flow rate of 0.2 $\mathrm{mL} / \mathrm{min}$ with slightly varying gradient slopes. Percent purity was in the range of that found with CZE or with HPLC under acidic conditions.

B. Capillary Zone Electrophoresis (CZE). CZE was carried out using a Beckman P/ACE System 2000 controlled by an IBM Personal System/2 model $50 Z$ and using a ChromJ et integrator. Electrophoresis was performed in $0.1 \mathrm{M}$ sodium phosphate $(\mathrm{pH} 2.5)$ except for $\alpha$-hel-CRF $(9-41)$ which was measured in $0.1 \mathrm{M}$ sodium borate ( $\mathrm{pH} 8.5)$. Acetonitrile (30\%) was added to the buffers in order to gain sharp elution profiles. ${ }^{35}$

C. Mass Spectroscopy. LSIMS mass spectra were measured with a J EOL J MS-HX110 double focusing mass spectrometer (J EOL, Tokyo, J apan) fitted with a $\mathrm{Cs}^{+}$gun. An accelerating voltage of $10 \mathrm{kV}$ and $\mathrm{Cs}^{+}$gun voltage of $25 \mathrm{kV}$ were employed; for further details, see ref 20 . Calculated values for protonated molecule ions were in agreement with those observed using liquid secondary ion mass spectrometry.

D. In Vitro Pituitary Cell Culture Assay. Rat anterior pituitary glands from male Sprague-Dawley rats were dissociated by collagenase treatment and plated $\left(0.16 \times 10^{6}\right.$ cells/ well in 48 -well plates) in medium containing $2 \%$ fetal bovine serum (FBS). ${ }^{27}$ Three days after plating, the cells were washed three times with fresh medium containing $0.1 \%$ bovine serum al bumin (BSA) and incubated for 1 h. Following the 1-h preincubation, the cells were washed once more and the test peptides were applied. At the end of a 3-h incubation period, the media were collected and the level of ACTH was deter- mined by radioimmunoassay (Diagnostic Products Corp.). When not mentioned, IA $=100 \%$.

E. In Vivo Adx Rat Assay. Adult male rats were adrenalectomized under halothane anesthesia 8 days prior to the experiments. Their diet was supplemented with oranges, and their water contained $0.9 \% \mathrm{NaCl}$. They were equipped with indwelling jugular cannulae $\mathrm{e}^{36} 48 \mathrm{~h}$ prior to the iv injection of the vehicle or the antagonists. All protocols were approved by the Salk I nstituteI ACU C. Astressin was first diluted in sterile distilled water, and the $\mathrm{pH}$ was adjusted to 7.0. Further dilutions were made in $0.04 \mathrm{M}$ phosphate buffer, $\mathrm{pH} 7.4$, containing $0.1 \%$ BSA and $0.01 \%$ ascorbic acid. Blood samples were obtained immediately before treatment as well as 15120 min later. Decanted plasma were frozen until assayed for ACTH concentrations with a commercially available kit (AIlegro Kit, Nichols Institute, San J uan Capistrano, CA). ${ }^{36}$

F. Reversal of Intracisternal CRF- and Abdominal Surgery-Induced Delay of Gastric Emptying. Animals: Adult male Sprague-Dawley rats (Harlan, San Diego, CA) weighing 250-280 g were used. Animals were housed in group cages with free access to food (Purina Rat Chow) and tap water and maintained at a 12:12-h light-dark cyde, under controlled temperature $\left(21-23^{\circ} \mathrm{C}\right)$. Animals were fasted, but had free access to water, for $18-20 \mathrm{~h}$ before experiments. All experimental protocols were approved by the Animal Use Committee of the West Los Angeles VA Medical Center.

Treatments: Peptides $\mathbf{2 2}$ and $\mathbf{2 3}$ were dissolved in doubly distilled HPLC water at $\mathrm{pH} 7.0$ warmed to $37^{\circ} \mathrm{C}$. Peptides (at doses of $0.1,0.3$, and $1 \mu \mathrm{g} / \mathrm{rat}$, in 5 - or $10-\mu \mathrm{L}$ volume as appropriate) were injected immediately before either CRF (0.6 $\mu \mathrm{g} / \mathrm{rat}, 5 \mu \mathrm{L}$, ic) administration or abdominal surgery. Intracisternal injections were performed acutely under short enflurane anesthesia $(2-3 \mathrm{~min})$ by puncture of the occipital membrane with a Hamilton syringe, in rats, placed in ear bars of a ster eotaxic equipment. Presence of CSF in the Hamilton syringe upon aspiration before injection ensured correctness of needle placement in the cisterna magna.

Measurement of Gastric Emptying: Gastric emptying was determined by the phenol red method, as previously described. ${ }^{10} \mathrm{~A}$ suspension of continuously stirred $1.5 \%$ methyl cellulose (Sigma Chemical Co., St. Louis, MO) and phenol red $(0.5 \%$, Sigma Chemical Co.) was given intragastrically $(1.5 \mathrm{~mL})$ to conscious rats. After a 20-min period, rats were euthanized by $\mathrm{CO}_{2}$ inhalation. The abdominal cavity was opened, the gastroesophageal junction and the pylorus were clamped, and the stomach was removed, rinsed in $0.9 \%$ saline, placed in 100 $\mathrm{mL}$ of $0.1 \mathrm{~N} \mathrm{NaOH}$, and homogenized (Polytron, Brinkmann Instruments). The suspension was allowed to settle for $1 \mathrm{~h}$ at room temperature, and then, $5 \mathrm{~mL}$ of the supernatant was added to $0.5 \mathrm{~mL}$ of $20 \%$ trichloroacetic acid (wt/vol) and then centrifuged at $3000 \mathrm{rpm}$ at $4{ }^{\circ} \mathrm{C}$ for $20 \mathrm{~min}$. The supernatant was mixed with $4 \mathrm{~mL}$ of $0.5 \mathrm{~N} \mathrm{NaOH}$ and the absorbance of the sample read at $560 \mathrm{~nm}$ (Shimazu 260 spectrophotometer). Phenol red recovered from animals euthanized immediately after the administration of the methyl cellulose solution was used as standard ( $0 \%$ emptying). Percent emptying in the 20 min period was calculated according to the following equation:

\section{$\%$ emptying $=(1-$ absorbance of text sample $) \times$ 100/absorbance of standard}

Experimental Protocols: 1. Intracisternal CRF-Induced Inhibition of Gastric Emptying. Under short enflurane anesthesia either $\left[\mathrm{DPh} \mathrm{e}^{12}, \mathrm{Nle}^{21,38}\right] \mathrm{CRF}_{(12-41)}$, astressin, 22, $23(0.1-10 \mu \mathrm{g} / \mathrm{rat})$, or vehicle $(5 \mu \mathrm{L})$ was injected ic immediately before the ic injection of either CRF $(0.6 \mu \mathrm{g} / \mathrm{rat})$ or vehicle $(5 \mu \mathrm{L})$ in fasted rats. The ic dose of CRF was selected to produce a $60 \%$ inhibition of gastric emptying when tested under the same experimental conditions in our previous doseresponse studies. ${ }^{10}$ After ic injections, animals were returned to their home cages, and $10 \mathrm{~min}$ later, the marker used for the measurement of gastric emptying of noncaloric liquid meals was administered to awake rats. The rate of gastric emptying was determined 20 min after the administration of the marker. 
2. Abdominal Surgery-Induced Inhibition of Gastric Emptying. Under 10-min exposure of enflurane anesthesia (5.5\% vapor concentration in $\mathrm{O}_{2}$; Ethrane-Anaquest) either vehicle $(10 \mu \mathrm{L})$ or astressin $(1,3$, or $10 \mu \mathrm{g} / \mathrm{rat})$ was injected ic and abdominal surgery with cecal manipulation was performed. Abdominal surgery consisted of a medial celiotomy $(3-4 \mathrm{~cm})$ and cecal exteriorization with cecal handling for a period of $1 \mathrm{~min}$ in gauze soaked with saline. The cecum was then returned to the abdominal cavity. The linea alba and the skin were sutured separately with 3-0 silk suture. The 20min rate of gastric emptying was measured at $160 \mathrm{~min}$ after the completion of abdominal surgery.

G. Statistical Analysis. $E D_{50}$, defined as the dose of peptide antagonist inducing a 50\% reversion of gastric ileus compared with the rate of emptying in vehicletreated rats (taken as $0 \%$ reversion), was determined by nonlinear regression to a sigmoidal equation with variable slope (Prism, version 2.0; GraphPad, San Diego, CA).

Acknowledgment. This work was supported in part by NIH Grants DK-26741 (J .R.), DK-33061 (Y.T.), and $\mathrm{MH}-00663$ (Y.T.), The Hearst Foundation, and the Foundation for Research, California Division. Drs. W. Vale, C. Rivier, and A. G. Craig are FR Investigators. We thank C. Miller, R. Kaiser, D. Kirby, T. Goedken, and Y. Haas for technical assistance, S. Lahrichi for the synthesis of $\mathbf{2 2}$ and 23, L. Cervini for critical review of the manuscript, and D. J ohns for manuscript preparation.

\section{References}

(1) Koerber, S. C.; Gulyas, J .; Lahrichi, S. L.; Corrigan, A.; Craig, A. G.; Rivier, C.; Vale, W.; Rivier, J . Constrained corticotropinreleasing factor (CRF) agonists and antagonists with $\mathrm{i}-(\mathrm{i}+3)$ Glu-Xaa-DXbb-Lys bridges. J. Med. Chem. 1998, 41, 50025011.

(2) Guillemin, R.; Rosenberg, B. Humoral hypothalamic control of anterior pituitary: a study with combined tissue cultures. Endocrinology 1955, 57, 599-607.

(3) Saffran, M.; Schally, A. V. The release of corticotrophin by anterior pituitary tissue in vitro. Can. J . Biochem. Physiol. 1955, 33, 408-415.

(4) Vale, W.; Spiess, J .; Rivier, C.; Rivier, J . Characterization of a 41 residue ovine hypothalamic peptide that stimulates the secretion of corticotropin and $\beta$-endorphin. Science 1981, 213, 1394-1397.

(5) Rivier, J .; Spiess, J .; Vale, W. Characterization of rat hypothalamic corticotropin-rel easing factor. Proc. Natl. Acad. Sci. U.S.A. 1983, 80, 4851-4855.

(6) Shibahara, S.; M orimoto, Y.; Furutani, Y.; Notake, M.; Takahashi, H.; Shimizu, S.; Horikawa, S.; Numa, S. Isolation and sequence analysis of the human corticotropin-releasing factor precursor gene. EMBO J . 1983, 2 (5), 775-779.

(7) Gulyas, J .; Rivier, C.; Perrin, M.; Koerber, S. C.; Sutton, S.; Corrigan, A.; Lahrichi, S. L.; Craig, A. G.; Vale, W.; Rivier, J. Potent, structurally constrained agonists and competitive antagonists of corticotropin releasing factor (CRF). Proc. Natl. Acad. Sci. U.S.A. 1995, 92, 10575-10579.

(8) Miranda, A.; Lahrichi, S. L.; Gulyas, J .; Koerber, S. C.; Craig A. G.; Corrigan, A.; Rivier, C.; Vale, W.; Rivier, J . Constrained corticotropin releasing factor (CRF) antagonists with $\mathrm{i}-(\mathrm{i}+3)$ Glu-Lys bridges. J. Med. Chem. 1997, 40, 3651-3658.

(9) Perrin, M. H.; Sutton, S. W.; Rivier, J. E.; Vale, W. W. Comparison of an agonist, urocortin, and an antagonist, astressin, as radioligands for characterization of CRF receptors. J PET 1998, in press.

(10) Martínez, V.; Rivier, J .; Wang, L.; Taché, Y. Central injection of a new corticotropin-rel easing factor (CRF) antagonist, astressin blocks CRF - and stress-related alterations of gastric and colonic motor function. J . Pharmacol. Exp. Ther. 1997, 280, 754-760.

(11) Chrousos, G. P.; Gold, P. W. Editorial: A healthy body in a healthy mind - and vice versa - the damaging power of "uncontrollable" stress. J . Clin. Endocrinol. Metab. 1998, 83, $1842-1845$.

(12) Baram, T. Z.; Mitchell, W. G.; Haden, E. Inhibition of pituitaryadrenal secretion by a corticotropin releasing hormone antagonist in humans. Mol. Psychiat. 1996, 1, 320-324.

(13) Chou, P. Y.; Fasman, G. D. Empirical predictions of protein conformation. Annu. Rev. Biochem. 1978, 47, 251-276.
(14) Pallai, P. V.; Mabilia, M.; Goodman, M.; Vale, W.; Rivier, J. Structural homology of corticotropin-releasing factor, sauvagine and urotensin I: Circular dichroism and prediction studies. Proc Natl. Acad. Sci. U.S.A. 1983, 80, 6770-6774.

(15) Romier, C.; Bernassau, J .-M.; Cambillau, C.; Darbon, H. Solution structure of human corticotropin releasing factor by ${ }^{1} \mathrm{H}$ NMR and distance geometry with restrained molecular dynamics. Protein Eng. 1993, 6, 149-156.

(16) Dathe, M.; Fabian, H.; Gast, K.; Zirwer, D.; Winter, R.; Beyermann, M.; Schumann, M.; Bienert, M. Conformational differences of ovine and human corticotropin releasing hormone. Int. J. Pept. Protein Res. 1996, 47, 383-393.

(17) Rivier, J .; Rivier, C.; Vale, W. Synthetic competitive antagonists of corticotropin releasing factor: Effect on ACTH secretion in the rat. Science 1984, 224, 889-891.

(18) Rivier, J .; Rivier, C.; Galyean, R.; Miranda, A.; Miller, C.; Craig, A. G.; Yamamoto, G.; Brown, M.; Vale, W. Single point Dsubstituted corticotropin releasing factor analogues: Effects on potency and physicochemical characteristics. J. Med. Chem. 1993, 36, 2851-2859.

(19) Hernandez, J -F.: Kornreich, W.: Rivier, C.: Miranda, A.: Yamamoto, G.; Andrews, J .; Taché, Y.; Vale, W.; Rivier, J . Synthesis and relative potencies of new constrained CRF antagonists. J. Med. Chem. 1993, 36, 2860-2867.

(20) Miranda, A.; Koerber, S. C.; Gulyas, J .; Lahrichi, S.; Craig, A. G.; Corrigan, A.; Hagler, A.; Rivier, C.; Vale, W.; Rivier, J. Conformationally restricted competitive antagonists of human/ rat corticotropin-rel easing factor. J . Med. Chem. 1994, 37, 14501459 .

(21) Felix, A. M.; Heimer, E. P.; Wang, C. T.; Lambros, T.J .; Fournier, A.; Mowles, T. F.; Maines, S.; Campbell, R. M.; Wegrzynski, B. B.; Toome, V.; Fry, D.; Madison, V. S. Synthesis, biological activity and conformational analysis of cyclic GRF analogues. Int. J . Pept. Protein Res. 1988, 32, 441-454.

(22) Rivier, J .; Lahrichi, S. L.; Gulyas, J .; Erchegyi, J .; Koerber, S. C.; Craig, A. G.; Corrigan, A.; Rivier, C.; Vale, W. Minimal-size, constrained corticotropin releasing factor agonists with $\mathrm{i}-(\mathrm{i}+3)$ Glu-Lys and Lys-Glu bridges. J. Med. Chem. 1998, 41, 26142620.

(23) Hudson, D. J . Methodological implications of simultaneous solidphase peptide synthesis. 1. Comparison of different coupling procedures. J . Org. Chem. 1988, 53, 617-624.

(24) Kaiser, E.; Colescott, R. L.; Bossinger, C. D.; Cook, P. I. Color test for detection of freeterminal amino groups in the solid-phase synthesis of peptides. Anal. Biochem. 1970, 34, 595-598.

(25) Hoeger, C.; Galyean, R.; Boublik, J.; McClintock, R.; Rivier, J. Preparative reversed phase high performance liquid chromatography. II. Effects of buffer $\mathrm{pH}$ on the purification of synthetic peptides. Biochromatography 1987, 2, 134-142.

(26) Rivier, J . Use of trialkylammonium phosphate (TAAP) buffers in reverse phase HPLC for high resolution and high recovery of peptides and proteins. J. Liq. Chromatogr. 1978, 1, 343-367.

(27) Vale, W.; Vaughan, J .; Yamamoto, G.; Bruhn, T.; Douglas, C.; Dalton, D.; Rivier, C.; Rivier, J . Assay of corticotropin releasing factor. In Methods in Enzymology: Neuroendocrine Peptides; Conn, P. M., Ed.; Academic Press: New York, 1983; Vol. 103, pp 565-577

(28) Shoemaker, K. R.; Kim, P. S.; York, E. J : Stewart, J. M.; Baldwin, R. L. Tests of the helix dipole model for stabilization of $\alpha$-helices. Nature 1987, 326, 563-567.

(29) Beyermann, M.; Fechner, K.; Furkert, I.; Krause, E.; Bienert, M. A single-point slight alteration set as a tool for structureactivity relationship studies of ovine corticotropin releasing factor. J . Med. Chem. 1996, 39, 3324-3330.

(30) Rivier, J .; Rivier, C.; Perrin, M.; Porter, J .; Vale, W. GnRH Analogues Structure-activity relationships. In LHRH Peptides as Female and Male Contraceptives; Zatuchni, G. I., Shelton, ]. D., Sciarra, J . . . Eds.; Harper and Row: Philadel phia, PA, 1981; pp 13-23.

(31) Rivier, J .; Porter, J .; Hoeger, C.; Theobald, P.; Craig, A. G. Dykert, J.; Corrigan, A.; Perrin, M.; Hook, W. A.; Siraganian, R. P.; Vale, W.; Rivier, C. Gonadotropin releasing hormone antagonists with $\mathrm{N}^{\omega}$-triazolyl-ornithine, -lysine or -para-aminophenylalanine residues at positions 5 and 6 . J. Med. Chem. 1992, 35, 4270-4278.

(32) Haskell-Luevano, C.; Boteju, L. W.; Miwa, H.; Dickinson, C. Gantz, I.; Yamada, T.; Hadley, M. E.; Hruby, V.J . Topographical modification of melanotropin peptide analogues with betamethyltryptophan isomers at position 9 leads to differential potencies and prolonged biological activities. J. Med. Chem. 1995, 38, 4720-4729.

(33) Kertscher, U.; Beyermann, M.; Krause, E.; Furkert, J .; Berger $\mathrm{H}$.; Bienert, M.; Mehlis, B. The degradation of corticotropinreleasing factor by enzymes of the rat brain studied by liquid chromatography - mass spectrometry. Peptides 1998, 19, 649658. 
(34) Felix, A. M.; Wang, C.-T.; Heimer, E. P.; Fournier, A. Applications of BOP reagent in solid-phase synthesis. II. Solid-phase side-chain to side-chain cyclizations using BOP reagent. Int. J . Pept. Protein Res. 1988, 31, 231-238.

(35) Miller, C.; Rivier, J. Analysis of synthetic peptides by capillary zone electrophoresis in organic/aqueous buffers. J. Pept. Res. 1998, 51, 444-451.
(36) Rivier, C.; Shen, G. H. In the rat, endogenous nitric oxide modulates the response of the hypothalamic-pituitary-adrenal axis to interleukin-1 $\beta$, vasopressin and oxytocin. J. Neurosci. 1994, 14, 1985-1993.

J M980426C 